\title{
Medical and surgical management of perianal Crohn's disease
}

\author{
Samuel O. Adegbola ${ }^{a, b}$, Anthea Pisanic, Kapil Sahnanª, , Phil Tozera,b, Pierre Ellulc, \\ Janindra Warusavitarne ${ }^{a, b}$
}

St. Mark's Hospital, Harrow, UK; Imperial College, London, UK; Mater dei Hospital, Malta

\section{Abstract}

Crohn's disease is increasingly thought to encompass multiple possible phenotypes. Perianal manifestations account for one such phenotype and represent an independent disease modifier. In its more severe form, perianal Crohn's disease confers a higher risk of a severe and disabling disease course, relapses, hospital admissions and operations. This, in turn, imposes a considerable burden and disability on patients. Identification of the precise manifestation is important, as management is nuanced, with both medical and surgical components, and is best undertaken in a multidisciplinary setting for both diagnosis and ongoing treatment. The introduction of biologic medication has heralded a significant addition to the management of fistulizing perianal Crohn's disease in particular, albeit with modest results. It remains a very challenging condition to treat and further work is required to optimize management in this group of patients.

Keywords Crohn's disease, perianal, surgery, medical therapy

Ann Gastroenterol 2018; 31 (1): 1-11

\section{Introduction}

Crohn's disease (CD) affects approximately 145 people per 100,000 population in the UK and between 4 and 250 people per 100,000 population worldwide, having a varied presentation [1]. Perianal CD (PCD) represents one phenotype [2] and is an independent disease modifier [3]. PCD encompasses a range of manifestations, from skin tags, to fissures, ulcers, strictures, abscesses, and fistulas. Various attempts have been made to classify these manifestations [4,5], but the uptake of these has been poor to date, possibly because of their limited clinical applicability and prognostic relevance, especially in relation to treatment [6]. In 2003, the American Gastroenterological Association (AGA) clinical practice committee adopted a pragmatic approach, classifying perianal lesions based on broad groupings of fistulizing manifestations (perianal and rectovaginal fistula/abscess) and non-fistulizing manifestations (skin tags, fissures, ulcers, anorectal stricture, hemorrhoids, anal cancer) [7].

Departments of a Colorectal Surgery St. Mark's Hospital, Harrow, United Kingdom (Samuel O. Adegbola, Kapil Sahnan, Phil Tozer, Janindra Warusavitarne); 'burgery and Cancer, Imperial College, London, United Kingdom (Samuel O. Adegbola, Kapil Sahnan, Phillip Tozer, Janindra Warusavitarne); 'Gastroenterology, Mater dei Hospital, Malta (Pierre Ellul)

\section{Conflict of Interest: None}

Correspondence to: Samuel Adegbola, St. Mark's Hospital, Watford Road, Harrow HA1 3UJ, e-mail: samadeg@doctors.net.uk

Received 23 August 2018; accepted 24 November 2017; published online 8 February 2018

DOI: https://doi.org/10.20524/aog.2018.0236
The true incidence of PCD is difficult to determine given the heterogeneity in definition and reporting [8]. A wide range of prevalence is reported [9] and accuracy is further hampered by the variable data sources (including single-center experiences and small population studies). Perianal fistulas account for a particularly disabling disease phenotype and occur in approximately a third of patients with CD $[7,10,11]$. The management of PCD is multidisciplinary and in this review we describe evidence-based surgical and medical aspects of treatment.

\section{Non-fistulizing manifestations}

The majority of studies of PCD focus on fistulas, whilst non-fistulizing disease is less well studied. Non-fistulizing manifestations can account for considerable morbidity if undiagnosed and untreated.

\section{Anal fissures}

The reported prevalence of anal fissures varies between $10-59 \%$ [12-15]. They can occur in any position, whereas in the absence of $\mathrm{CD}$ they are usually found in the midline, posteriorly $[15,16]$. Often painless, they can however, still present with pain and bleeding. The etiology is thought to be inflammatory rather than due to the high anal tone/ischemia seen in non-CD fissures.

Fifty percent of fissures could heal spontaneously with treatment of the underlying CD [17]. In those that persist, 
topical therapy (glyceryl trinitrate/diltiazem ointment) can sometimes be effective in improving symptoms [14,17], although this is paradoxical from an etiological point of view. Other treatments include steroids, antibiotics and aminosalicylates, and retrospective studies suggest that about half of patients show some response to these [18]. Anti-tumor necrosis factor (TNF)- $\alpha$ therapy has also been used in the management of fissures. Bouguen et al [19] retrospectively reviewed the records of treated cases across two tertiary referral centers, reporting that $70 \%(24 / 34)$ of fissures treated with infliximab healed over a median follow up of 3 years. Surgical options described for medically refractory fissures include lateral internal sphincterotomy, fissurectomy or advancement flap closure. Sphincterotomy carries a risk of minor incontinence in patients without chronic, diarrhea-causing inflammatory bowel disease (IBD). Given that sphincter tone is not the presumed mechanism, it is not recommended in $\mathrm{CD}$, although there have been reported successes in small numbers [13]. The authors do not advocate this approach.

\section{Anal ulceration}

Anal ulceration is thought to be common in the context of PCD (Fig. 1A,B). A retrospective review by Bouguen et al [19] reported that 94 of 99 patients with non-fistulizing PCD treated with infliximab infusions had ulceration. Siproudhis et al [17] report a prevalence of $67 \%$ (43/64) in consecutive CD patients with anal lesions referred to a tertiary institution. Other studies have reported lower rates $[8,20]$, perhaps reflecting case mix or

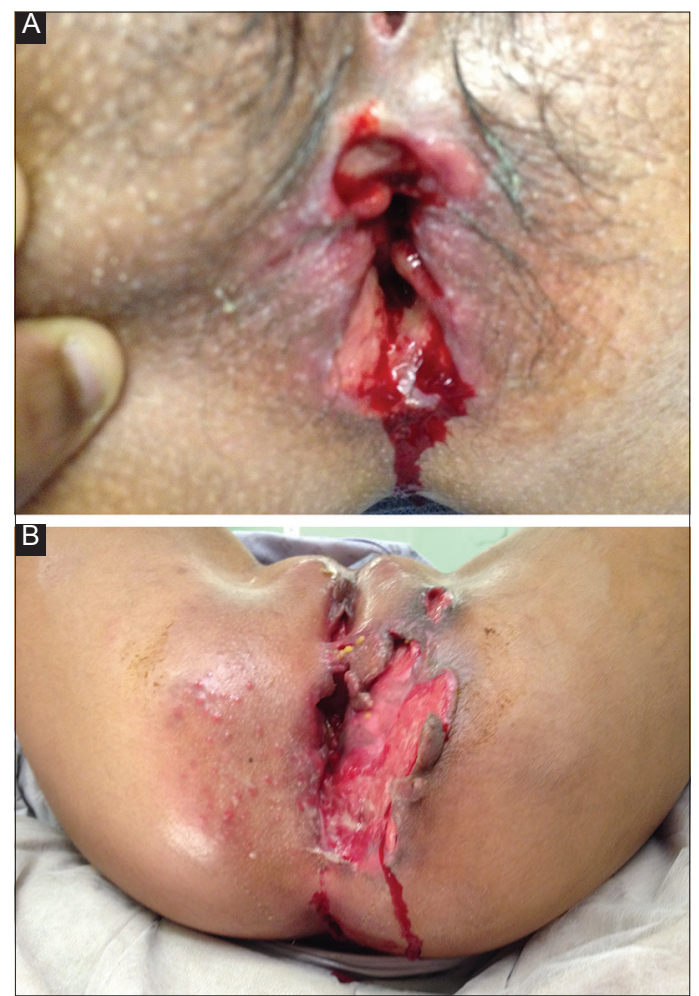

Figure 1 (A and B) small and massive anal ulceration in patients with perianal crohn's disease differences in classification, as some confuse superficial fissures with cavitating ulcers [5]. Anal ulceration is often associated with proctitis [17] and can present with pain, pruritus, discharge and bleeding [19]. Management options include topical treatments such as metronidazole for short-term improvement of symptoms [21], and topical tacrolimus, which has been shown to improve ulcer depth, surface area and appearance in the short term [22]. Infliximab is also beneficial, with up to $83 \%$ complete resolution at long-term follow up $[19,23]$. Ouraghi et al reported short-term (<6 months) response rates in in $63 \%$ $(10 / 16)$ of patients with fissures/ulcers, with significant relapse rates $(61 \%)$ at 1 year. Bouguen et al reported complete response in $72 \%$ of patients at 3 years [19].

\section{Anal stenosis / stricture}

Strictures may follow ulceration, often in the presence of proctitis [24]. Symptoms include bloody diarrhea, constipation, perianal pain, and incontinence [24]. Examination under anesthetic and imaging allow assessment of the stricture, whilst biopsies should be taken to exclude malignancy.

Treatment options include dilatation using Hegar dilators, reported to lower the likelihood of fecal diversion [25]. Following initial dilatation under general anesthetic, patients can continue self-dilatation at home. Treatment with anti-TNF therapy has been reported to be successful. Bouguen et al [19] report complete regression of strictures in $55 \%$ of cases (12/22) at 3-year follow up following infliximab treatment. Infliximab was concomitant with anal dilatation in half those with complete regression. Plastic surgical techniques may also be considered, but the risk of wound breakdown warrants caution, especially in the presence of proctitis.

A retrospective review of the natural history of 102 patients with CD-related anorectal strictures reported 59\% (52/88) healing after a median follow up of 2.8 years with multimodal treatment [26]. Strictures are associated with an increased likelihood of fecal diversion. Galandiuk et al [25] prospectively analyzed consecutive patients $(n=86)$ undergoing treatment for PCD. They demonstrated that anal strictures were associated with an increased risk of permanent stoma on univariate analysis (odds ratio [OR] 3.0, 95\% confidence interval [CI] 1.22-7.67; $\mathrm{P}=0.02$ ) and multivariate analysis (OR 3.69, 95\%CI 1.39-10.7; $\mathrm{P}=0.01)$. The presence of colonic disease in association with anal canal stricturing showed a fivefold risk of permanent stoma on multivariate analysis (OR 5.73, 95\%CI 1.49-27.0; $\mathrm{P}=0.016)$.

\section{Skin tags and hemorrhoids}

Skin tags are a common manifestation of PCD [27,28] (Fig. 2). The "large edematous type" are thought to arise secondary to lymphatic obstruction [5]. They are hard and cyanotic, usually coexistent with fissures and often symptomatic (pain/discomfort). The "elephant ears" type are flat, soft and usually asymptomatic. Excision may be sought to ameliorate symptoms, but it is important to discuss the risks of impaired 
wound healing or perianal ulceration [29]. Limited rather than extensive excision may reduce the risk of subsequent stenosis.

Symptomatic hemorrhoids are thought to be relatively uncommon in $\mathrm{CD}$ patients compared with the general population [14]. Data on surgical treatment are sparse with poorly measured outcomes, making assessment difficult $[14,30,31]$. In general, surgical treatment is rarely required.

\section{Anal cancer}

The incidence of anal cancer is not known but it is thought to be rare [32]. There are reports of an association between complicated PCD and cancer in the anorectum [32-35]. Diagnosis is often delayed because of the distorted anatomy in longstanding PCD. A heightened suspicion is often required in the context of prolonged perianal disease and a low threshold for clinical evaluation and biopsies should be adopted. Management is the same as for anal malignancy of non-IBD origin; however, the risks of wound-related complications are higher in CD.

\section{Fistulizing manifestations - perianal fistula and abscess}

Multidisciplinary management of PCD is strongly advised as gold-standard care [36]. Active luminal disease should be treated with the aim of inducing and maintaining remission [37]. Prior to the use of immunosuppressive medications any perianal sepsis needs to be drained. Steroids should be avoided as they do not have a role in management [38].

\section{Medical management}

\section{Antibiotics (ciprofloxacin/metronidazole)}

In a systematic review of randomized controlled trials (RCTs) on the use of antibiotics in IBD, three trials evaluated perianal fistulas and showed a significant reduction in fistula drainage (relative risk $0.8,95 \%$ CI $0.66-0.98$ ) with no heterogeneity $(\mathrm{I} 2=0 \%)$ [40]. Usual dosages of metronidazole are $20 \mathrm{mg} / \mathrm{kg} /$ day or $750-1000 \mathrm{mg} /$ day divided into 3 or 4 doses, whilst the dosage of ciprofloxacin is $1000-1500 \mathrm{mg} /$ day divided into 2 doses. In most studies therapy lasted for 8-12 weeks. Long-term use is limited by side-effects and drug resistance [38,39]. However, antibiotics rarely lead to complete or sustained healing and symptoms recur on cessation [37].

\section{Immunomodulatory treatment}

Thiopurines. Perianal fistula (Fig. 2) at diagnosis is considered a poor prognostic marker and patients may benefit most from early introduction of immunomodulators or

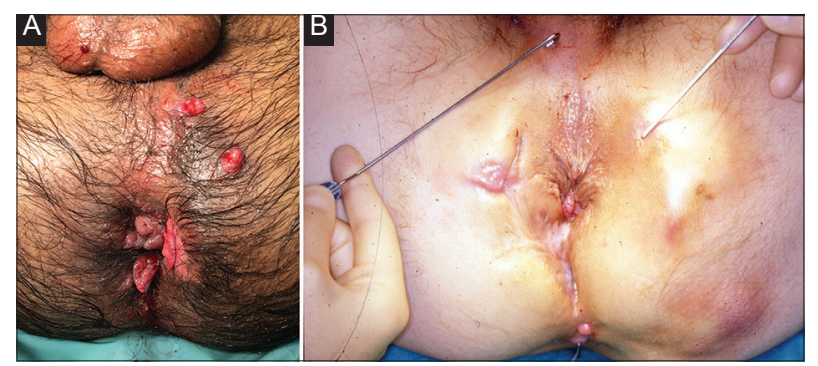

Figure 2 (A) Patient with skin tags and fistula with multiple external openings, (B) Fistula with multiple external openings, and scaring from previous surgery

biological therapy [37]. Azathioprine and 6-mercaptopurine are antimetabolite agents with immunosuppressive properties that have been shown to be effective in the management of luminal CD [40].

In a meta-analysis of five RCTs carried out in 1995, perianal fistula response was assessed as a secondary endpoint and was seen in $54 \%(22 / 49)$ compared to $21 \%(6 / 29)$ in the placebo group (pooled OR 4.44, 95\%CI 1.50-13.2) [41]. Fistula response was defined as complete healing or decreased discharge, using $2-3 \mathrm{mg} / \mathrm{kg}$ azathioprine or $1.5 \mathrm{mg} / \mathrm{kg}$ 6-mercaptopurine. These immunomodulators may not produce a response for three months (or longer) with implications for acute management [42].

Calcineurin inhibitors. A study by Sandborn et al.[43] demonstrated that tacrolimus $(0.2 \mathrm{mg} / \mathrm{kg} /$ day $)$ was effective in improving symptoms $(43 \%$ vs. $8 \%, \mathrm{P}<0.05)$, but not fistula closure $(\mathrm{P}=0.86)$. A more recent study evaluated the role of tacrolimus in patients with severe $\mathrm{CD}$ intolerant or unresponsive to anti-TNF agents.

In a retrospective study, intravenous cyclosporine followed by oral cyclosporine achieved complete closure in about 33\% of patients, but the response was lost after discontinuation [44]. The limited data on intravenous cyclosporine in PCD come from uncontrolled case series including fewer than 100 patients [37]. Its place in the management of PCD is unclear.

Anti-TNF-a therapy. Infliximab, adalimumab, and certolizumab have been shown to be effective as both induction and maintenance therapy in moderate to severe $\mathrm{CD}$, including patients with fistulas. A meta-analysis performed by Kawalec et al [45] included 19 clinical trials, of which seven evaluated anti-TNF agents for the treatment of fistulizing $\mathrm{CD}$, though only two of these trials were designed specifically to address this issue. During induction and maintenance, significantly more patients achieved a $\geq 50 \%$ reduction in draining fistulas (clinical response) versus placebo (relative benefit $[\mathrm{RB}] 1.70, \mathrm{P}=0.04$, and $\mathrm{RB} 1.84$, $\mathrm{P}=0.001$, respectively) and complete fistula closure (clinical remission) ( $\mathrm{RB} 2.44, \mathrm{P}=0.02$, and $\mathrm{RB} 2.03, \mathrm{P}=0.0003$ ) [45]. Fistula outcomes in trials of medical treatment have mainly used clinical assessment to determine response and remission. Assessment with magnetic resonance imaging (MRI) has demonstrated that deep fistula healing lags behind clinical remission by a year [46]. 


\section{Infliximab}

The first anti-TNF- $\alpha$ agent shown to be effective in an RCT for inducing and maintaining closure of perianal fistulas was infliximab, an IgG1 murine-human chimeric monoclonal antibody. In the trial, $68 \%$ of patients with perianal fistulas who received the $5 \mathrm{mg} / \mathrm{kg}$ dose had a clinical response, compared with $26 \%$ receiving placebo $(\mathrm{P}=0.002)$. Fistula closure was observed in $55 \%$ of patients versus $13 \%$ in the placebo group $(\mathrm{P}=0.001)$. The median length of time to response was 2 weeks and fistulas remained closed for approximately 3 months [47]. The ACCENT II trial, a multicenter, double-blind, randomized, placebo-controlled trial evaluating the efficacy of maintenance infliximab, confirmed the initial response and showed that, after 54 weeks of therapy, $46 \%$ of patients in the infliximab arm had a sustained response versus $23 \%$ in the placebo arm $(\mathrm{P}=0.001)$ [48]. ACCENT II also demonstrated that infliximab significantly reduced hospitalizations and surgery in this group of patients [49]. Despite these favorable results, abscess development was observed in $10-15 \%$ of cases, most likely secondary to external fistula closure. Nevertheless, it is unclear whether this rate is higher than the spontaneous rate of abscess formation in patients with fistulas [50]. Further data from ACCENT II concluded that abscess formation was not dependent on cumulative infliximab exposure [51]. A retrospective study showed that about two thirds of patients treated with infliximab for fistulizing PCD for a median of 250 weeks experienced fistula closure, though one third of patients had fistula recurrence after initial fistula closure. The study also revealed that, in addition to long-term infliximab, combination therapy with thiopurines was associated with better outcomes [52]. A recent cross-sectional study demonstrated that achieving serum infliximab drug levels of more than $\geq 10.1 \mu \mathrm{g} / \mathrm{mL}$ in patients with perianal fistulas improved outcomes [53]. This might form part of a treat-totarget strategy.

\section{Adalimumab}

Adalimumab is a fully human, anti-TNF monoclonal antibody. The data on the effect of adalimumab on PCD is derived mainly from studies where fistula closure or improvement was a secondary endpoint. Initial data on fistula closure from the CLASSIC-1 trial [54] and the GAIN study [55] did not show superiority of adalimumab to placebo. In the CHARM trial, $30 \%$ of patients with perianal fistulas treated with adalimumab for 26 weeks had fistula closure compared to the closure rate of $13 \%$ with placebo $(\mathrm{P}<0.04)$ [56]. By week 56 the fistula closure was $33 \%$ in the adalimumab group (controls $13 \%, \mathrm{P}<0.02)$. The CHOICE trial assessed patients who had previously failed to respond to infliximab and were prescribed adalimumab. Complete fistula healing by date of last visit (with last visit dates ranging from just 4 to 36 weeks) was achieved in $40 \%$ [57]. A number of retrospective studies in both infliximab-naïve and treated patients have shown adalimumab to be effective in the treatment of perianal fistulas [58-61].

\section{Certolizumab pegol}

Certolizumab pegol is a humanized, PEGylated, Fc-free anti-TNF monoclonal antibody. It has been evaluated in perianal fistulizing CD by way of randomized double-blind controlled trials in the PRECiSE studies [62-64]. Responders ( $\geq 100$-point decrease from baseline CD Activity Index [CDAI]) with draining fistulas following induction treatment with certolizumab were randomized to certolizumab pegol $400 \mathrm{mg}(\mathrm{n}=28)$ or placebo $(\mathrm{n}=30)$ as maintenance therapy with assessment at week 26. Most had perianal fistulas (55/58). Fifteen of the 28 patients (54\%) had protocol-defined fistula closure ( $\geq 50 \%$ closure at two consecutive post-baseline visits $\geq 3$ weeks apart) compared with $13 / 30$ (43\%) in the placebo group. This result was not statistically significant $(\mathrm{P}=0.069)$. Interestingly, it was noted that a subgroup analysis of an altered definition of fistula closure, i.e., "those patients with $100 \%$ fistula closure", demonstrated a significant difference between certolizumab and placebo ( $36 \%$ vs. $17 \%, \mathrm{P}=0.038$ ) [65].

Combination therapies. Several combination regimens have been explored. A double-blind placebo-controlled study found that a combination of ciprofloxacin and infliximab improved Perianal Disease Activity Index compared to infliximab alone. However, the $73 \%$ clinical response in the combination treatment group (vs. 39\% in the placebo and infliximab group) was not statistically significant $(\mathrm{P}=0.12)$ [66]. Combination ciprofloxacin and adalimumab treatment has also demonstrated benefit, with a clinical response in $71 \%$ of patients in the combined treatment group versus $47 \%$ in the adalimumab alone group $(\mathrm{P}=0.047)$. Combination treatment was associated with a greater change in mean CDAI and mean IBD Questionnaire score at week 12 ( $\mathrm{P}=0.005$ and $\mathrm{P}=0.009$, respectively). In the latter study, the difference between the two groups with regards to fistula closure rate was not maintained 12 weeks after discontinuation of the antibiotic therapy $(\mathrm{P}=0.22)$ [67].

Combination of anti-TNF therapy with immunomodulators (e.g., thiopurines) has been assessed. Combination with an immunomodulator has the additional potential beneficial effects of decreasing anti-drug antibody formation as well as drug clearance for all anti-TNF agents [68]. A meta-analysis in 2015, pooling data from 11 RCTs, demonstrated no apparent benefit from combination therapy as regards partial (OR 1.25, 95\%CI $0.84-1.88$ ) or complete fistula closure (OR 1.1, 95\%CI 0.68-1.78) [69].

Current guidance suggests a combination therapy of ciprofloxacin and anti-TNF. Thiopurines may be added to enhance the effect of anti-TNF [37].

Vedolizumab. There are limited data on the role and efficacy of vedolizumab in PCD. In the GEMINI II trial, vedolizumab, an $\alpha_{4} \beta_{7}$ integrin monoclonal antibody, demonstrated a higher rate of fistula closure than placebo $(41.2 \%$ vs. $11 \%$, $\mathrm{P}=0.03$ ) [70]. In addition, the maintenance intention-to-treat population with fistulizing disease was analyzed. Some $28 \%$ of patients given vedolizumab as sole treatment maintained fistula closure at one year versus $11 \%$ of those who received placebo maintenance [71]. In view of the small numbers, no 
definitive recommendation can be made regarding the use of vedolizumab in PCD.

Ustekinumab. Ustekinumab is active against the p40 subunit of interleukin-12 and interleukin-23. Its role in perianal fistulizing disease has been evaluated in small studies. In a retrospective analysis of $45 \mathrm{CD}$ patients with perianal fistulas, $31.1 \%(n=14)$ achieved complete healing as demonstrated by pelvic MRI or dedicated pelvic contrastenhanced ultrasound [72]. In patients with anti-TNF refractory disease, Battat et al [51] reported that at $\geq 6$ months $4 / 6$ patients had a $>50 \%$ reduction from baseline in the number of draining fistulas, with $2 / 6$ patients having closure of all fistulas. In a similar study [73], perianal disease improved (on the basis of physician judgement) in 11 of 18 (61\%) patients with active perianal fistulas. Larger studies are required to define ustekinumab's role in perianal Crohn's fistula treatment.

Other options. Other drugs, such as mycophenolate mofetil, methotrexate and thalidomide, are not currently recommended for standard routine clinical practice [74]. Exclusive enteral nutrition (EEN) is an established treatment option in children with CD [75]. A case series that included three children with perianal disease at diagnosis showed that EEN, together with surgery and antibiotics, was effective in inducing disease remission and assisted in the healing of the perianal disease [76]. Its role in the adult population with PCD has not been studied.

\section{Surgical management}

The fistula anatomy, disease activity and presence of complicating features (proctitis, abscess) influence surgical options. The AGA [7] empirically distinguishes fistulas as simple or complex, with the former having higher rates of healing. Simple fistulas are classified as superficial or low intersphincteric/transsphincteric with a single external opening, no pain or fluctuation to suggest perianal abscess, no evidence of a rectovaginal fistula, and no evidence of anorectal stricture. Complex fistulas (Fig. 2A,B), in contrast, are high fistulas (intersphincteric / transsphincteric / extrasphincteric / suprasphincteric) and may be associated with multiple external openings, presence of pain or fluctuation to suggest a perianal abscess, presence of a rectovaginal fistula, presence of an anorectal stricture, or presence of active rectal disease at endoscopy [7].

Management of fistulizing PCD has evolved from a focus on definitive surgical repair to multidisciplinary management, with surgical drainage in preparation for medical treatment. In many circumstances surgery can be a good adjunct to symptom palliation. Diversion or ablation are offered in the case of failure.

\section{Examination under anesthesia (EUA) with drainage of collections / seton insertion}

EUA and drainage is the first-line treatment for acute abscess so as to control local sepsis prior to initiating medical treatment [36]. Loose setons maintain patency of fistula tracts, limiting recurrent abscess formation $[77,78]$. When the goal of medical treatment is fistula closure, the seton must be removed, often towards the end of anti-TNF treatment induction [77], although the optimal timing of removal is unknown. Loose setons may be left in situ permanently to control local sepsis and reduce symptoms, although on occasion they may need to be replaced. Loose setons also serve as a bridge between optimization of medical therapy and definitive surgical treatment. Cutting setons, by contrast, are a method of fistulotomy and risk sphincter injury and the authors do not advocate this in perianal Crohn's fistula $[6,77]$.

\section{Definitive surgical options / curative procedures}

Advancement flaps. Advancement flaps involve raising a flap of tissue adjacent to the internal opening of a fistula, excising the internal opening and securing the flap to cover it [79]. This approach aims to close the high-pressure end of the fistula and disconnect the tract from the gut [80]. Several small studies have reported on variations of advancement flaps, with healing rates varying from $40-80 \%$ [80-82] and incontinence rates of approximately $9 \%$, usually from flaps involving the internal sphincter [82]. Flap procedures avoid external wounds, which can be associated with impaired healing and perineal scarring [6]. The procedure is thought to be easier in patients with perineal descent and internal intussusception [6]. Relative contraindications include proctitis, cavitating ulceration and anal stenosis [83]. The evidence to support routine use in CD is limited.

In-fill materials (fibrin glue, fistula plug). These techniques have the benefit of having no impact on the sphincter mechanism and can be repeated in the presence of recurrence. Fibrin glue aims to seal the tract by activating thrombin to form a fibrin clot $[84,85]$. This clot may facilitate the wound healing process, although evidence for this is lacking. Success rates are very variable (0-100\%) [86], reflecting small numbers, varying techniques and limited follow up in the studies published. A review in 2009 reported a 35\% (13/37) healing rate in six studies [86] and an RCT in 2010 had a 20\% (11/54) remission rate for patients with CD (at median follow up of 37 months) $[6,87]$. Longer-term healing rates are lacking.

Anal fistula plugs are bioprosthetic devices thought to promote wound healing [88]. They elicit no foreign body or inflammatory reaction and provide a collagen scaffold populated by a patient's endogenous cells over approximately three months $[89,90]$. As with glue, the evidence is heterogeneous, lacking robust methodology, with widely variable healing as a result of the small numbers of CD patients studied (15-100\%) [82,91-93]. A systematic review in 2012 reported the pooled proportion of patients achieving closure with a fistula plug in 42 patients with CD was 55\% (95\%CI 0.39-0.70) [91].

Despite poor primary healing, in-fill materials may serve as scaffolds for delivering stem cells and local pharmaceuticals [94]. A phase II multicenter study of complex 
fistula (14 of 49 patients had PCD) compared glue vs. glue plus expanded adipose-derived stem cells (ASCs) with healing in $16 \%$ vs. $71 \%$ respectively [94].

Stem cell therapy. Adult mesenchymal stem cells (MSCs), including ASCs, are a promising tool for treating inflammatory and autoimmune diseases because of their immunomodulatory capacity and paracrine effects through trophic factors with antifibrotic, anti-apoptotic, or proangiogenic properties [95,96]. Stem cell therapy mainly transplants autologous or allogeneic stem cells into patients. Several trials have demonstrated the safety and efficacy of local administration of MSCs into the Crohn's perineal fistulas [97103]. These have so far demonstrated that the technique is safe and initial studies have impressive healing rates. Recently, the results of a phase III RCT investigating the efficacy of allogeneic ASCs for the treatment of PCD were reported. Among 212 patients randomized, 107 patients received a single injection of $120 \times 10^{6}$ MSCs and 105 received placebo. At 24 weeks, the MSC-treated patients had significantly higher rates of combined remission, defined as closure of the external fistula tract and absence of fluid collections $>2 \mathrm{~cm}$ on MRI; $50 \%$ (53/107) healed in the MSC group compared with $34 \%(36 / 105)$ in the placebo group $(\mathrm{P}=0.024)$. This beneficial effect was maintained at week 52 (56.3\% vs. $38.6 \%$, respectively, $\mathrm{P}=0.01$ ) [103]. Additionally, MSC-treated patients had a significantly shorter time to clinical remission ( 6.7 vs. 14.6 weeks). The higher than expected success rate in the placebo arm was thought to be attributable to the fact that all patients underwent fistula curettage, surgical drainage, and closure of the internal orifice, which can result in healing irrespective of MSC delivery [104]. An alternate explanation could be the low threshold for defining clinical and radiological remission. The absence of collections $>2 \mathrm{~cm}$ in at least 2 of 3 dimensions means that a significant volume of undrained sepsis may still have been present and yet described as remission. Despite this, almost all patients enrolled in trials for stem cells were refractory to standard therapy and, regardless of the origin of the MSCs, or the dose and method of administration, results have largely suggested superior efficacy compared with conventional therapy in a difficult-to-treat subgroup [104]. A systematic review and meta-analysis including 14 studies $(n=477)$ [105], revealed that MSCs had significantly better efficacy compared with other treatments (risk difference 0.21 , $\mathrm{P}=0.0004)$. The review also showed that, after MSC treatment, the group with a higher baseline CDAI had a higher healing rate and clinical response compared to the group with a lower CDAI (79.17 vs. $47.53, \mathrm{P}=0.011$ ). A moderate dose of $2-4 \times 10^{7}$ cells $/ \mathrm{mL}$ had a higher healing rate and a lower recurrence rate compared to other dosages, whilst adipose-derived MSCs had an advantage over bone marrow-derived MSCs [105]. Follow up is generally short. The longest follow up comes from a group where 10 patients were followed up for 6 years after autologous bone marrow-derived MSCs. The cumulative probabilities of surgery- and medical-free survival were $100 \%$ and $88 \%$ at 1 year and $63 \%$ and $25 \%$ at 6 years, with no adverse events being recorded [106].

Stem cell treatment appears to be safe and, whether alone or in combination with other modalities, may generate improved healing and symptomatic relief. Despite the promising results, the ideal type of MSC, appropriate dosage, uniform protocol for cell isolation and the number of injections still require clarification [107].

\section{Other techniques: ligation of intersphincteric fistula tract (LIFT), over-the-scope clip (OTSC), fistula tract laser closure (FiLaC), video-assisted anal fistula treatment (VAAFT)}

LIFT procedure involves ligation and excision of the fistula tract in the intersphincteric space. Two studies have published results from Crohn's perianal fistulas. Gingold et al reported their experience in a small series of 15 patients. There was $67 \%$ $(8 / 12)$ success (clinical healing) at 12 months with no reports of incontinence $[6,108]$. A more recent retrospective singlecenter study by Kaminsky et al [109] reported healing in 75\% $(6 / 8)$ at $<12$ months follow up and $33 \%(5 / 15)$ in patients with follow up of more than one year.

Other emerging sphincter sparing procedures include VAAFT [110,111], FiLaC [112,113], and OTSC [114,115]. Preliminary data on patients treated with VAAFT reported an $80 \%(8 / 10)$ success rate at median follow up of 9 months when combined with an advancement flap. Mennigen et al. reported success with the OTSC in 4/5 treated patients with Crohn's perianal fistulas [114]. Wilhelm et al.reported a $69.2 \%$ $(9 / 13)$ success rate in patients with Crohn's perianal fistula treated with FiLaC. There were no reports of any continence impairment in any of these studies. Current data for CD are sparse, so it is impossible to draw meaningful conclusions at this stage [116]. The potential benefit here lies with the minimally invasive nature of the procedures and the fact that patients may accept multiple attempts at these techniques, even with the relatively uncertain outcome, provided there is no risk to continence.

\section{Fecal diversion}

The challenging nature of Crohn's perianal fistula renders sustained fistula remission often unachievable, despite multiple surgical procedures combined with best medical therapy [46]. Diverting the fecal stream aims to control the inflammatory burden with concomitant medical therapy in order improve quality of life and avoid proctectomy [117,118]. Galandiuk et al [25] reported $62 \%(53 / 86)$ of patients with fistulizing PCD required fecal diversion at some point during their care. A systematic review reported that two-thirds of patients (from a pooled analysis of 14 studies including 373 patients) experienced a clinical response within 6 months of diversion [119]. The exact response is difficult to quantify, especially as the nature of reporting clinical response is heterogeneous in the literature and often subject to bias. Furthermore, "early fistula response" is often short-lived and clinical remission may not correlate with MRI-proven deep tissue healing $[46,120,121]$. The effect of temporary diversion on remission rates is modest [122,123]. Singh et al also reported in their review that restoration of continuity was attempted in $34.5 \%$ patients and only successful 


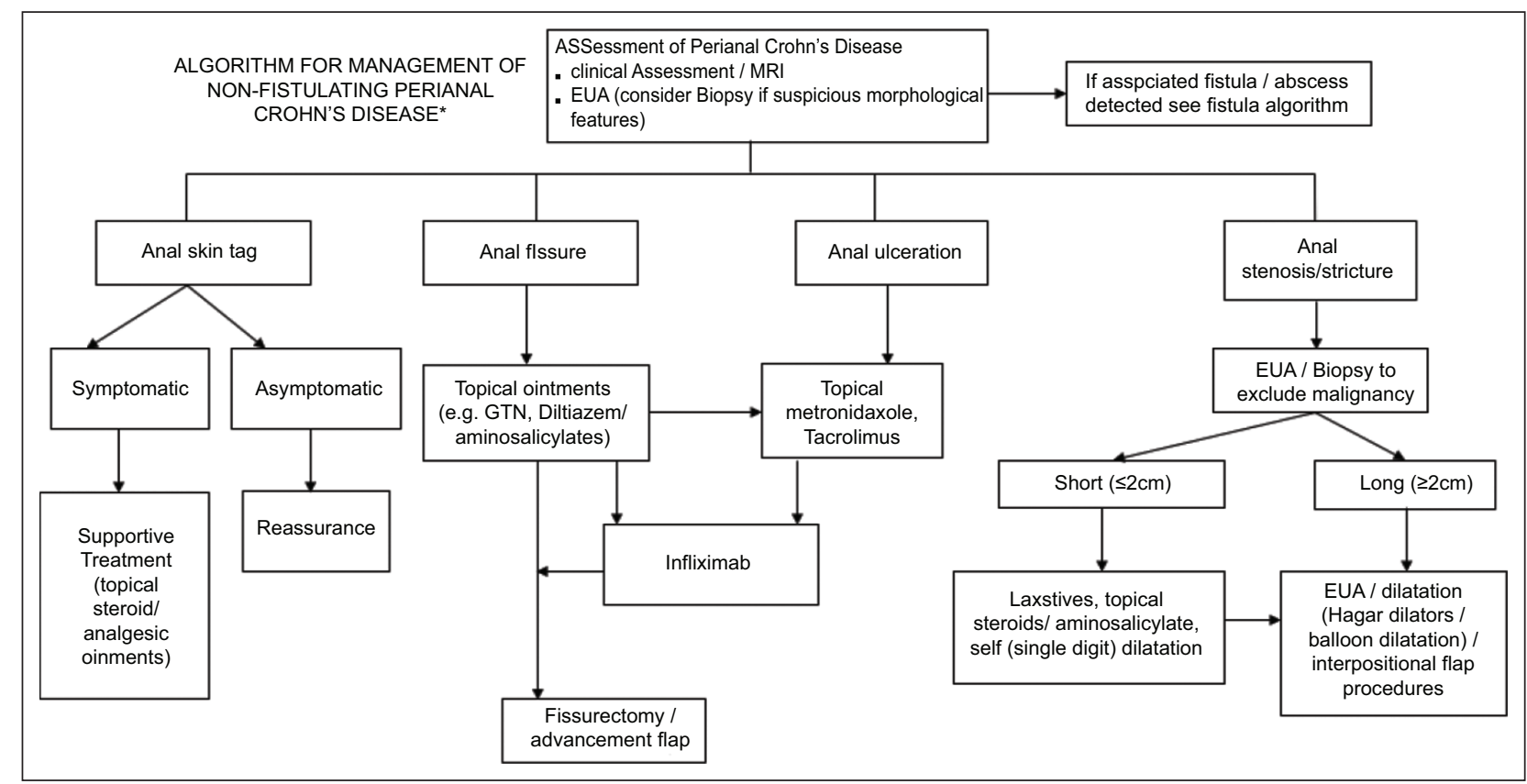

Figure 3 Algorithm reproduced from 'Management of Perianal Crohn's Disease in the Biologic Era', Coloproctology - A Practical Guide (Eds. Beynon, Harris, Davies, Evans) 2017 Chapter 1 (pgs 1-27), Adegbola SO, et al; Copyright Information - Springer International Publishing AG 2017, reproduced with permission of Springer

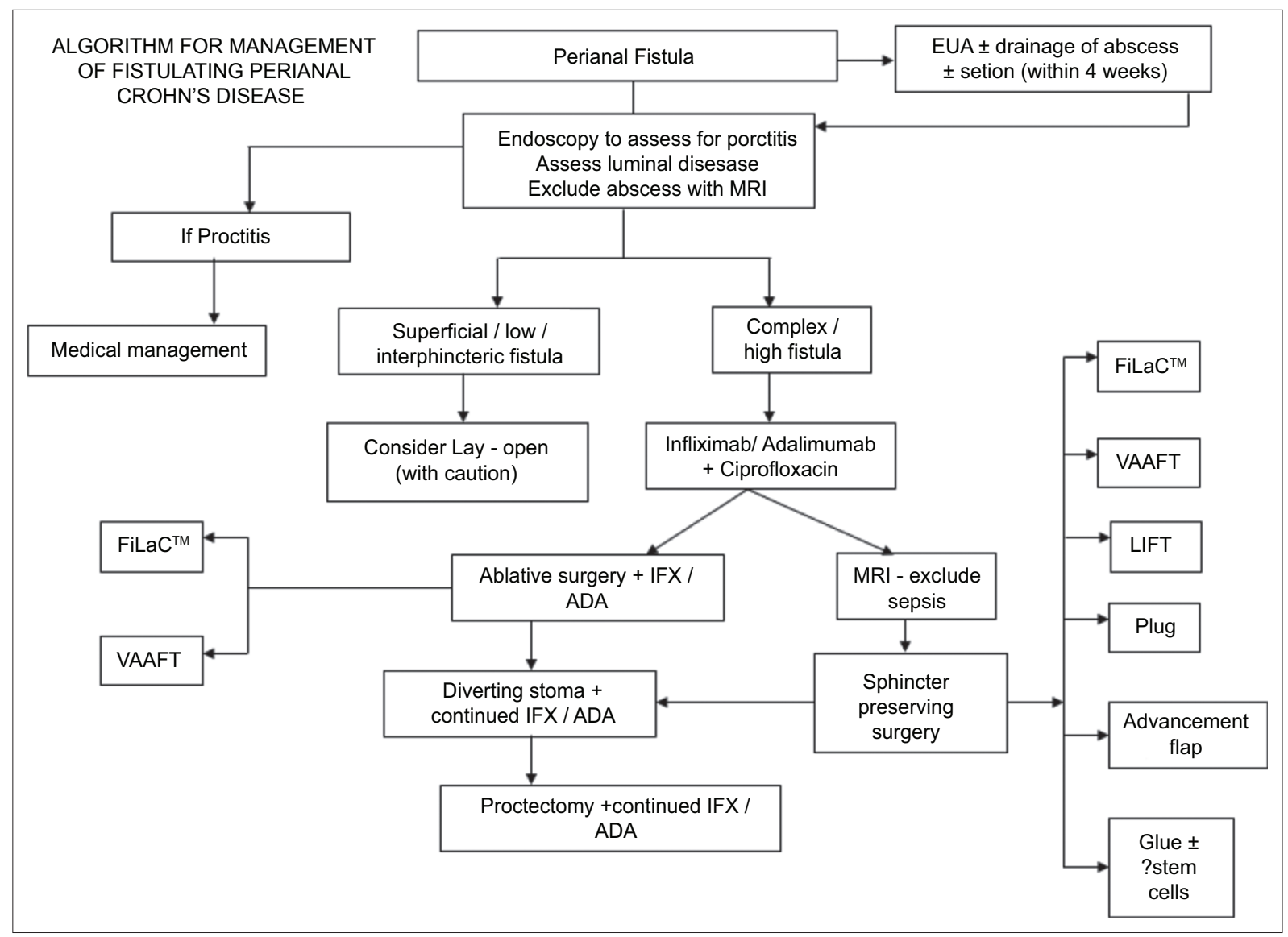

Figure 4 Algorithm reproduced from 'Management of Perianal Crohn's Disease in the Biologic Era', Coloproctology - A Practical Guide (Eds. Beynon, Harris, Davies, Evans) 2017 Chapter 1 (pgs 1-27), Adegbola SO, et al; Copyright Information - Springer International Publishing AG 2017, reproduced with permission of Springer 
in half. This suggests that "temporary" fecal diversion, is more often a bridge towards permanent diversion or proctectomy. The advent of biological treatment has not made a significant difference to the risk of diversion [119,124]. Successful restoration rates also remain low [119]. Studies suggest that the most important factor precluding restoration of bowel continuity is the presence of proctitis $[124,125]$. Other factors include multiple seton placement for fistulizing disease and other aggressive disease characteristics [124].

Temporary diversion may offer a psychological role particularly in younger patients in whom irreversible diversion (i.e., proctectomy) may be too daunting [126]. Diversion appears to have a role in improving quality of life (QoL), as demonstrated by good global QoL scores in general with patients who have undergone fecal diversion [127]. Kasparek et al [127] reported a trend toward a better quality of life with fecal diversion (using a variety of generic QoL scores) in their analysis of patients with PCD. They reported that $79 \%$ of undiverted patients complained of CD symptoms, compared to $44 \%$ in the diverted group. These questionnaires are, however, non-specific and there remains a lack of validated patientreported outcome measures specific to perianal disease. Such scores would be able to demonstrate robustly an improvement targeted towards patients whose QoL with aggressive disease and concomitant proctitis leaves them with few therapeutic options. Fecal diversion may well trigger the dilemma of the willingness to trade the risks and consequences of permanent fecal diversion for an improved quality of life. Unfortunately, proctectomy can be complicated by poor wound healing and perineal sinus formation in up to $25-50 \%$ of patients and may necessitate plastic surgical techniques to help combat these complications [128].

\section{Rectovaginal fistulas}

CD accounts for the most common cause of rectovaginal fistulas [83] after obstetric trauma. Medical management is similar to that of perianal fistulas; however, curative surgical management options are limited. Higher fistulas and those with active proctitis or originating from a Bartholin's abscess have a higher chance of failure $[129,130]$. Advancement flap procedures can be a curative option and can be performed transanally or transvaginally. Ruffolo et al [129] reviewed 11 studies that reported on flap procedures, with 224 flaps performed for rectovaginal fistulas in $\mathrm{CD}$, and a comparison of transrectal and transvaginal approaches demonstrated that pooled primary closure (53\% vs. 61\%) and pooled overall closure $(75 \%$ vs. $81 \%)$ were similar with both approaches. El-Gazzaz et al [131] evaluated long-term outcomes in 65 women with Crohn's rectovaginal fistulas who underwent a variety of different procedures, of which the advancement flap was the most common. At a median follow up of 47 months, $46 \%$ remained healed. Multivariate analysis showed that immunomodulators were associated with successful healing $(\mathrm{P}=0.009)$, whereas smoking and steroids were associated with failure $(\mathrm{P}=0.04)$.

\section{Concluding remarks}

The management of PCD represents a challenging field in IBD. Most studies examined perianal fistula. The biologic era, despite showing major promise in IBD, has offered only limited efficacy in long-term management, particularly of fistulizing PCD. Furthermore, the literature is diluted by heterogeneity in classification, technique, and outcome measurement. The limited conclusions that can be drawn suggest that best treatment comes from combination of medical and surgical therapies [132]. The list of surgical techniques, particularly for fistula, is expanding and there is a need to evaluate these techniques with robust and uniform outcome measures [133]. Multidisciplinary management is essential [Figs. 3 and 4]. Shared management using joint clinics with gastroenterologists and surgeons could lead to better outcomes and form the basis of many national standards to ensure best practice.

\section{References}

1. Tarrant KM, Barclay ML, Frampton CM, Gearry RB. Perianal disease predicts changes in Crohn's disease phenotype-results of a population-based study of inflammatory bowel disease phenotype. Am J Gastroenterol 2008;103:3082-3093.

2. Tang LY, Rawsthorne P, Bernstein CN. Are perineal and luminal fistulas associated in Crohn's disease? A population-based study. Clin Gastroenterol Hepatol 2006;4:1130-1134.

3. Satsangi J, Silverberg MS, Vermeire S, Colombel JF. The Montreal classification of inflammatory bowel disease: controversies, consensus, and implications. Gut 2006;55:749-753.

4. Hughes LE. Surgical pathology and management of anorectal Crohn's disease. J R Soc Med 1978;71:644-651.

5. Hughes LE. Clinical classification of perianal Crohn's disease. Dis Colon Rectum 1992;35:928-932.

6. Pellino G, Selvaggi F. Surgical treatment of perianal fistulizing Crohn's disease: from lay-open to cell-based therapy - an overview. ScientificWorldJournal 2014;2014:146281.

7. Sandborn WJ, Fazio VW, Feagan BG, Hanauer SB; American Gastroenterological Association Clinical Practice Committee. AGA technical review on perianal Crohn's disease. Gastroenterology 2003;125:1508-1530.

8. Singh B, McC Mortensen NJ, Jewell DP, George B. Perianal Crohn's disease. Br J Surg 2004;91:801-814.

9. Eglinton TW, Barclay ML, Gearry RB, Frizelle FA. The spectrum of perianal Crohn's disease in a population-based cohort. Dis Colon Rectum 2012;55:773-777.

10. Tozer P, Borowski DW, Gupta A, Yassin N, Phillips R, Hart A. Managing perianal Crohn's fistula in the anti-TNFa era. Tech Coloproctol 2015;19:673-678.

11. Juncadella AC, Alame AM, Sands LR, Deshpande AR. Perianal Crohn's disease: a review. Postgrad Med 2015;127:266-272.

12. Wolff BG, Culp CE, Beart RW Jr, Ilstrup DM, Ready RL. Anorectal Crohn's disease. A long-term perspective. Dis Colon Rectum 1985;28:709-711.

13. Fleshner PR, Schoetz DJ Jr, Roberts PL, Murray JJ, Coller JA, Veidenheimer MC. Anal fissure in Crohn's disease. Dis Colon Rectum 1995;38:1137-1143.

14. D’Ugo S, Franceschilli L, Cadeddu F, et al. Medical and surgical treatment of haemorrhoids and anal fissure in Crohn's disease: a critical appraisal. BMC Gastroenterol 2013;13:47. 
15. Sweeney JL, Ritchie JK, Nicholls RJ. Anal fissure in Crohn's disease. Br J Surg 1988;75:56-57.

16. Buchmann P, Keighley MR, Allan RN, Thompson H, AlexanderWilliams J. Natural history of perianal Crohn's disease. Ten year follow-up: a plea for conservatism. Am J Surg 1980;140:642-644.

17. Siproudhis L, Mortaji A, Mary JY, Juguet F, Bretagne JF, Gosselin M. Anal lesions: any significant prognosis in Crohn's disease? Eur J Gastroenterol Hepatol 1997;9:239-243.

18. Bouguen G, Siproudhis L, Bretagne JF, Bigard MA, PeyrinBiroulet L. Nonfistulizing perianal Crohn's disease: clinical features, epidemiology, and treatment. Inflamm Bowel Dis 2010;16:1431-1442.

19. Bouguen G, Trouilloud I, Siproudhis L, et al. Long-term outcome of non-fistulizing (ulcers, stricture) perianal Crohn's disease in patients treated with infliximab. Aliment Pharmacol Ther 2009;30:749-756.

20. Platell C, Mackay J, Collopy B, Fink R, Ryan P, Woods R. Anal pathology in patients with Crohn's disease. Aust $N Z J$ Surg 1996;66:5-9.

21. Stringer EE, Nicholson TJ, Armstrong D. Efficacy of topical metronidazole (10 percent) in the treatment of anorectal Crohn's disease. Dis Colon Rectum 2005;48:970-974.

22. Hart AL, Plamondon S, Kamm MA. Topical tacrolimus in the treatment of perianal Crohn's disease: exploratory randomized controlled trial. Inflamm Bowel Dis 2007;13:245-253.

23. Ouraghi A, Nieuviarts S, Mougenel JL, et al. Infliximab therapy for Crohn's disease anoperineal lesions. Gastroenterol Clin Biol 2001;25:949-956.

24. Linares L, Moreira LF, Andrews H, Allan RN, Alexander-Williams J, Keighley MR. Natural history and treatment of anorectal strictures complicating Crohn's disease. Br J Surg 1988;75:653-655.

25. Galandiuk S, Kimberling J, Al-Mishlab TG, Stromberg AJ. Perianal Crohn disease: predictors of need for permanent diversion. Ann Surg 2005;241:796-801.

26. Brochard C, Siproudhis L, Wallenhorst T, et al. Anorectal stricture in 102 patients with Crohn's disease: natural history in the era of biologics. Aliment Pharmacol Ther 2014;40:796-803.

27. Sangwan YP, Schoetz DJ Jr, Murray JJ, Roberts PL, Coller JA. Perianal Crohn's disease. Results of local surgical treatment. Dis Colon Rectum 1996;39:529-535.

28. Bonheur JL, Braunstein J, Korelitz BI, Panagopoulos G. Anal skin tags in inflammatory bowel disease: new observations and a clinical review. Inflamm Bowel Dis 2008;14:1236-1239.

29. Keighley MR, Allan RN. Current status and influence of operation on perianal Crohn's disease. Int J Colorectal Dis 1986;1:104-107.

30. Jeffery PJ, Parks AG, Ritchie JK. Treatment of haemorrhoids in patients with inflammatory bowel disease. Lancet 1977;1:1084-1085.

31. Wolkomir AF, Luchtefeld MA. Surgery for symptomatic hemorrhoids and anal fissures in Crohn's disease. Dis Colon Rectum 1993;36:545-547.

32. Frisch M, Johansen C. Anal carcinoma in inflammatory bowel disease. Br J Cancer 2000;83:89-90.

33. Somerville KW, Langman MJ, Da Cruz DJ, Balfour TW, Sully L. Malignant transformation of anal skin tags in Crohn's disease. Gut 1984;25:1124-1125.

34. Ky A, Sohn N, Weinstein MA, Korelitz BI. Carcinoma arising in anorectal fistulas of Crohn's disease. Dis Colon Rectum 1998;41:992-996.

35. Frisch M, Glimelius B, van den Brule AJ, et al. Benign anal lesions, inflammatory bowel disease and risk for high-risk human papillomavirus-positive and -negative anal carcinoma. $\mathrm{Br}$ J Cancer 1998;78:1534-1538.

36. Sahnan K, Adegbola SO, Tozer PJ, Watfah J, Phillips RK. Perianal abscess. BMJ 2017;356:j475

37. Gionchetti P, Dignass A, Danese S, et al. 3rd European Evidence- based Consensus on the Diagnosis and Management of Crohn's Disease 2016: Part 2: Surgical Management and Special Situations on behalf of ECCO. J Crohns Colitis 2017;1 1:135-149.

38. Aguilera-Castro L, Ferre-Aracil C, Garcia-Garcia-de-Paredes A, Rodriguez-de-Santiago E, Lopez-Sanroman A. Management of complex perianal Crohn's disease. Ann Gastroenterol 2017;30:33-44.

39. Khan KJ, Ullman TA, Ford AC, et al. Antibiotic therapy in inflammatory bowel disease: a systematic review and metaanalysis. Am J Gastroenterol 2011;106:661-673.

40. Bär F, Sina C, Fellermann K. Thiopurines in inflammatory bowel disease revisited. World J Gastroenterol 2013;19:1699-1706.

41. Pearson DC, May GR, Fick GH, Sutherland LR. Azathioprine and 6-mercaptopurine in Crohn disease. A meta-analysis. Ann Intern Med 1995;123:132-142.

42. Present DH, Korelitz BI, Wisch N, Glass JL, Sachar DB, Pasternack BS. Treatment of Crohn's disease with 6-mercaptopurine. A long-term, randomized, double-blind study. $N$ Engl J Med 1980;302:981-987.

43. Sandborn WJ, Present DH, Isaacs KL, et al. Tacrolimus for the treatment of fistulas in patients with Crohn's disease: a randomized, placebo-controlled trial. Gastroenterology 2003;125:380-388.

44. Cat H, Sophani I, Lemann M, Modiglani R, Solue JC. Cyclosporin treatment of anal and perianal lesions associated with Crohn's disease. Turk J Gastroenterol 2003;14:121-127.

45. Kawalec P, Mikrut A, Wiśniewska N, Pilc A. Meta-analysis/ systematic review tumor necrosis factor- $\alpha$ antibodies (infliximab, adalimumab and certolizumab) in Crohn's disease: systematic review and meta-analysis. Arch Med Sci 2013;9:765-779

46. Tozer P, Ng SC, Siddiqui MR, et al. Long-term MRI-guided combined anti-TNF- $\alpha$ and thiopurine therapy for Crohn's perianal fistulas. Inflamm Bowel Dis 2012;18:1825-1834.

47. Present DH, Rutgeerts $\mathrm{P}$, Targan $\mathrm{S}$, et al. Infliximab for the treatment of fistulas in patients with Crohn's disease. N Engl J Med 1999;340:1398-1405.

48. Sands BE, Anderson FH, Bernstein $\mathrm{CN}$, et al. Infliximab maintenance therapy for fistulizing Crohn's disease. $N$ Engl J Med 2004;350:876-885.

49. Lichtenstein GR, Yan S, Bala M, Blank M, Sands BE. Infliximab maintenance treatment reduces hospitalizations, surgeries, and procedures in fistulizing Crohn's disease. Gastroenterology 2005; 128:862-869.

50. Bressler B, Sands BE. Review article: Medical therapy for fistulizing Crohn's disease. Aliment Pharmacol Ther 2006;24:1283-1293.

51. Sands BE, Blank MA, Diamond RH, Barrett JP, Van Deventer SJ. Maintenance infliximab does not result in increased abscess development in fistulizing Crohn's disease: results from the ACCENT II study. Aliment Pharmacol Ther 2006;23:1127-1136.

52. Bouguen G, Siproudhis L, Gizard E, et al. Long-term outcome of perianal fistulizing Crohn's disease treated with infliximab. Clin Gastroenterol Hepatol 2013;11:975-981.e1-4.

53. Yarur AJ, Kanagala V, Stein DJ, et al. Higher infliximab trough levels are associated with perianal fistula healing in patients with Crohn's disease. Aliment Pharmacol Ther 2017;45:933-940.

54. Hanauer SB, Sandborn WJ, Rutgeerts P, et al. Human anti-tumor necrosis factor monoclonal antibody (adalimumab) in Crohn's disease: the CLASSIC-I trial. Gastroenterology 2006;130:323-333.

55. Sandborn WJ, Rutgeerts P, Enns R, et al. Adalimumab induction therapy for Crohn disease previously treated with infliximab: a randomized trial. Ann Intern Med 2007;146:829-838.

56. Colombel JF, Sandborn WJ, Rutgeerts P, et al. Adalimumab for maintenance of clinical response and remission in patients with Crohn's disease: the CHARM trial. Gastroenterology 2007;132:52-65.

57. Lichtiger S, Binion DG, Wolf DC, et al. The CHOICE trial: adalimumab demonstrates safety, fistula healing, improved quality 
of life and increased work productivity in patients with Crohn's disease who failed prior infliximab therapy. Aliment Pharmacol Ther 2010;32:1228-1239.

58. Castaño-Milla C, Chaparro M, Saro C, et al. Effectiveness of adalimumab in perianal fistulas in Crohn's disease patients naive to anti-TNF therapy. J Clin Gastroenterol 2015;49:34-40.

59. Fortea-Ormaechea JI, González-Lama Y, Casis B, et al. Adalimumab is effective in long-term real life clinical practice in both luminal and perianal Crohn's disease. The Madrid experience. Gastroenterol Hepatol 2011;34:443-448.

60. Kotze PG, Spinelli A. Adalimumab for perianal fistulizing Crohn's disease: real-world data adds important information for clinical practice. J Clin Gastroenterol 2015;49:174-175.

61. Echarri A, Castro J, Barreiro M, Carpio D, Pereira S, Lorenzo A. Evaluation of adalimumab therapy in multidisciplinary strategy for perianal Crohn's disease patients with infliximab failure. J Crohns Colitis 2010;4:654-660.

62. Schreiber S, Khaliq-Kareemi M, Lawrance IC, et al. PRECISE 2 Study Investigators. Maintenance therapy with certolizumab pegol for Crohn's disease. N Engl J Med 2007;357:239-250.

63. Sandborn WJ, Feagan BG, Stoinov S, et al. Certolizumab pegol for the treatment of Crohn's disease. N Engl J Med 2007;357:228-238.

64. Schreiber S, Lawrance IC, Thomsen O, Hanauer SB, Bloomfield R, Sandborn WJ. Randomised clinical trial: certolizumab pegol for fistulas in Crohn's disease - subgroup results from a placebocontrolled study. Aliment Pharmacol Ther 2011;33:185-193.

65. Schreiber S. Certolizumab pegol for the treatment of Crohn's disease. Therap Adv Gastroenterol 2011;4:375-389.

66. West RL, van der Woude CJ, Hansen BE, et al. Clinical and endosonographic effect of ciprofloxacin on the treatment of perianal fistulae in Crohn's disease with infliximab: a double-blind placebocontrolled study. Aliment Pharmacol Ther 2004;20:1329-1336.

67. Dewint P, Hansen BE, Verhey E, et al. Adalimumab combined with ciprofloxacin is superior to adalimumab monotherapy in perianal fistula closure in Crohn's disease: a randomised, double-blind, placebo controlled trial (ADAFI). Gut 2014;63:292-299.

68. Colombel JF, Feagan BG, Sandborn WJ, Van Assche G, Robinson AM. Therapeutic drug monitoring of biologics for inflammatory bowel disease. Inflamm Bowel Dis 2012;18:349-358.

69. Jones JL, Kaplan GG, Peyrin-Biroulet L, et al.; Effects of concomitant immunomodulator therapy on efficacy and safety of anti-tumor necrosis factor therapy for Crohn's disease: a metaanalysis of placebo-controlled trials. Clin Gastroenterol Hepatol 2015;13:2233-2240.e1-e2.

70. Sandborn WJ, Feagan BG, Rutgeerts P, et al. GEMINI 2 Study Group. Vedolizumab as induction and maintenance therapy for Crohn's disease. N Engl J Med 2013;369:711-721.

71. Feagan B, Schwartz D, Danese S, et al. Vedolizumab for the treatment of fistulising Crohn's disease: an exploratory analysis of data from GEMINI 2. J Crohns Colitis 2015;9 Suppl 1:S333-S334.

72. Ma C, Fedorak RN, Kaplan GG, et al. Clinical, endoscopic and radiographic outcomes with ustekinumab in medically-refractory Crohn's disease: real world experience from a multicentre cohort. Aliment Pharmacol Ther 2017;45:1232-1243.

73. Khorrami S, Ginard D, Marín-Jiménez I, et al. Ustekinumab for the treatment of refractory Crohn邓s disease.: the Spanish experience in a large multicentre open-label cohort. Inflamm Bowel Dis 2016;22:1662-1669.

74. Mahadevan U, Marion JF, Present DH. Fistula response to methotrexate in Crohn's disease: a case series. Aliment Pharmacol Ther 2003; 18:1003-1008.

75. Ruemmele FM, Veres G, Kolho KL, et al.; European Society of Pediatric Gastroenterology, Hepatology and Nutrition. Consensus guidelines of ECCO/ESPGHAN on the medical management of pediatric Crohn's disease. J Crohns Colitis 2014;8:1179-1207.
76. Wong S, Lemberg DA, Day AS. Exclusive enteral nutrition in the management of perianal Crohn's disease in children. J Dig Dis 2010;11:185-188.

77. Gecse KB, Bemelman W, Kamm MA, et al.; World Gastroenterology Organization International Organisation for Inflammatory Bowel Diseases IOIBD European Society of Coloproctology and Robarts Clinical Trials. A global consensus on the classification, diagnosis and multidisciplinary treatment of perianal fistulising Crohn's disease. Gut 2014;63:1381-1392.

78. Hyder SA, Travis SP, Jewell DP, McC Mortensen NJ, George BD. Fistulating anal Crohn's disease: results of combined surgical and infliximab treatment. Dis Colon Rectum 2006;49:1837-1841.

79. Ruffolo C, Citton M, Scarpa M, et al. Perianal Crohn's disease: is there something new? World J Gastroenterol 2011;17:1939-1946.

80. Mizrahi N, Wexner SD, Zmora O, et al. Endorectal advancement flap: are there predictors of failure? Dis Colon Rectum 2002;45:1616-1621.

81. Göttgens KW, Smeets RR, Stassen LP, Beets GL, Pierik M, Breukink SO. Treatment of Crohn's disease-related high perianal fistulas combining the mucosa advancement flap with platelet-rich plasma: a pilot study. Tech Coloproctol 2015;19:455-459.

82. Soltani A, Kaiser AM. Endorectal advancement flap for cryptoglandular or Crohn's fistula-in-ano. Dis Colon Rectum 2010;53:486-495.

83. Sordo-Mejia R, Gaertner WB. Multidisciplinary and evidencebased management of fistulizing perianal Crohn's disease. World J Gastrointest Pathophysiol 2014;5:239-251.

84. Grimaud J, Munoz-Bongrand N, Siproudhis L, et al. Fibrin glue is effective healing perianal fistulas in patients with Crohn's disease. Gastroenterology 2010;138:2275-2281.

85. Vitton V, Gasmi M, Barthet M, Desjeux A, Orsoni P, Grimaud JC. Long-term healing of Crohn's anal fistulas with fibrin glue injection. Aliment Pharmacol Ther 2005;21:1453-1457.

86. Cirocchi R, Farinella E, La Mura F, et al. Fibrin glue in the treatment of anal fistula: a systematic review. Ann Surg Innov Res 2009;3:12.

87. Grimaud JC, Munoz-Bongrand N, Siproudhis L, et al.; Groupe d'Etude Thérapeutique des Affections Inflammatoires du Tube Digestif. Fibrin glue is effective healing perianal fistulas in patients with Crohn's disease. Gastroenterology 2010;138:2275-2281, 2281.e1.

88. Senéjoux A, Siproudhis L, Abramowitz L, et al. Fistula plug in fistulising ano-perineal Crohn's disease: a randomised controlled trial. J Crohns Colitis 2016;10:141-148.

89. Champagne BJ, O'Connor LM, Ferguson M, Orangio GR, Schertzer ME, Armstrong DN. Efficacy of anal fistula plug in closure of cryptoglandular fistulas: long-term follow-up. Dis Colon Rectum 2006;49:1817-1821.

90. Kelley KA, Kaur T, Tsikitis VL. Perianal Crohn's disease: challenges and solutions. Clin Exp Gastroenterol 2017;10:39-46.

91. O’Riordan JM, Datta I, Johnston C, Baxter NN. A systematic review of the anal fistula plug for patients with Crohn's and nonCrohn's related fistula-in-ano. Dis Colon Rectum 2012;55:351-358.

92. Taxonera C, Schwartz DA, García-Olmo D. Emerging treatments for complex perianal fistula in Crohn's disease. World J Gastroenterol 2009; 15:4263-4272.

93. Ky AJ, Sylla P, Steinhagen R, Steinhagen E, Khaitov S, Ly EK. Collagen fistula plug for the treatment of anal fistulas. Dis Colon Rectum 2008;51:838-843.

94. Garcia-Olmo D, Herreros D, Pascual I, et al. Expanded adiposederived stem cells for the treatment of complex perianal fistula: a phase II clinical trial. Dis Colon Rectum 2009;52:79-86.

95. Singer NG, Caplan AI. Mesenchymal stem cells: mechanisms of inflammation. Annu Rev Pathol 2011;6:457-478.

96. DelaRosa O, Dalemans W, Lombardo E. Mesenchymal stem cells as therapeutic agents of inflammatory and autoimmune diseases. Curr Opin Biotechnol 2012;23:978-983. 
97. Lee WY, Park KJ, Cho YB, et al. Autologous adipose tissuederived stem cells treatment demonstrated favorable and sustainable therapeutic effect for Crohn's fistula. Stem Cells 2013;31:2575-2581.

98. Ciccocioppo R, Bernardo ME, Sgarella A, et al. Autologous bone marrow-derived mesenchymal stromal cells in the treatment of fistulising Crohn's disease. Gut 2011;60:788-798.

99. de la Portilla F, Alba F, García-Olmo D, Herrerías JM, González FX, Galindo A. Expanded allogeneic adipose-derived stem cells (eASCs) for the treatment of complex perianal fistula in Crohn's disease: results from a multicenter phase I/IIa clinical trial. Int J Colorectal Dis 2013;28:313-323.

100. Molendijk I, Bonsing BA, Roelofs $\mathrm{H}$, et al. Allogeneic bone marrow-derived mesenchymal stromal cells promote healing of refractory perianal fistulas in patients with Crohn's disease. Gastroenterology 2015;149:918-927.e6.

101. García-Olmo D, García-Arranz M, Herreros D, Pascual I, Peiro C, Rodríguez-Montes JA. A phase I clinical trial of the treatment of Crohn's fistula by adipose mesenchymal stem cell transplantation. Dis Colon Rectum 2005;48:1416-1423.

102. Cho YB, Lee WY, Park KJ, Kim M, Yoo HW, Yu CS. Autologous adipose tissue-derived stem cells for the treatment of Crohn's fistula: a phase I clinical study. Cell Transplant 2013;22:279-285.

103. Panés J, García-Olmo D, Van Assche G, et al.; ADMIRE CD Study Group Collaborators. Expanded allogeneic adipose-derived mesenchymal stem cells (Cx601) for complex perianal fistulas in Crohn's disease: a phase 3 randomised, double-blind controlled trial. Lancet 2016;388:1281-1290.

104. Lightner AL, Faubion WA. Mesenchymal stem cell injections for the treatment of perianal Crohn's disease: what we have accomplished and what we still need to do. J Crohns Colitis 2017;11:1267-1276.

105. Cao Y, Ding Z, Han C, Shi H, Cui L, Lin R. Efficacy of mesenchymal stromal cells for fistula treatment of Crohn's disease: a systematic review and meta-analysis. Dig Dis Sci 2017;62:851-860.

106. Ciccocioppo R, Gallia A, Sgarella A, Kruzliak P, Gobbi PG, Corazza GR. Long-term follow-up of Crohn disease fistulas after local injections of bone marrow-derived mesenchymal stem cells. Mayo Clin Proc 2015;90:747-755.

107. Grégoire C, Lechanteur C, Briquet A, et al. Review article: mesenchymal stromal cell therapy for inflammatory bowel diseases. Aliment Pharmacol Ther 2017;45:205-221.

108. Gingold DS, Murrell ZA, Fleshner PR. A prospective evaluation of the ligation of the intersphincteric tract procedure for complex anal fistula in patients with Crohn disease. Ann Surg 2013;260:1057-1061.

109. Kamiński JP, Zaghiyan K, Fleshner P. Increasing experience of LIFT procedure for patients with Crohn's disease: what have we learned? Colorectal Dis 2017;19:750-755.

110. Grolich T, Skricka T, Robek O, Kala Z, Hemmelová B, Hrivnák R. Role of video assisted anal fistula treatment in our management of fistula-in-ano. Acta Chir Iugosl 2014;61:83-85.

111. Schwandner O. Video-assisted anal fistula treatment (VAAFT) combined with advancement flap repair in Crohn's disease. Tech Coloproctol 2013;17:221-225.

112. Giamundo P, Esercizio L, Geraci M, Tibaldi L, Valente M. Fistula-tract laser closure (FiLaCTM): long-term results and new operative strategies. Tech Coloproctol 2015;19:449-453.

113. Wilhelm A, Fiebig A, Krawczak M. Five years of experience with the FiLaCTM laser for fistula-in-ano management: long-term followup from a single institution. Tech Coloproctol 2017;21:269-276.

114. Mennigen R, Laukötter M, Senninger N, Rijcken E. The OTSC $\left(^{(}\right)$ proctology clip system for the closure of refractory anal fistulas. Tech Coloproctol 2015;19:241-246.

115. Gautier M, Godeberge P, Ganansia R, et al.; Groupe de Recherche en Proctologie SNFCP France. Easy clip to treat anal fistula tracts: a word of caution. Int J Colorectal Dis 2015;30:621-624.

116. Adegbola SO, Sahnan K, Pellino G, et al. Short-term efficacy and safety of three novel sphincter-sparing techniques for anal fistulae: a systematic review. Tech Coloproctol 2017;21:775-782.

117. Edwards CM, George BD, Jewell DP, Warren BF, Mortensen NJ, Kettlewell MG. Role of a defunctioning stoma in the management of large bowel Crohn's disease. Br J Surg 2000;87:1063-1066.

118. Sauk J, Nguyen D, Yajnik V, et al. Natural history of perianal Crohn's disease after fecal diversion. Inflamm Bowel Dis 2014;20:2260-2265.

119. Singh S, Ding NS, Mathis KL, et al. Systematic review with metaanalysis: faecal diversion for management of perianal Crohn's disease. Aliment Pharmacol Ther 2015;42:783-792.

120. Rasul I, Wilson SR, MacRae H, Irwin S, Greenberg GR. Clinical and radiological responses after infliximab treatment for perianal fistulizing Crohn's disease. Am J Gastroenterol 2004;99:82-88.

121. Schwartz DA, White CM, Wise PE, Herline AJ. Use of endoscopic ultrasound to guide combination medical and surgical therapy for patients with Crohn's perianal fistulas. Inflamm Bowel Dis 2005; 11:727-732.

122. Burman JH, Thompson H, Cooke WT, Williams JA. The effects of diversion of intestinal contents on the progress of Crohn's disease of the large bowel. Gut 1971;12:11-15.

123. Hong MK, Craig Lynch A, Bell S, et al. Faecal diversion in the management of perianal Crohn's disease. Colorectal Dis 2011;13:171-176.

124. Gu J, Valente MA, Remzi FH, Stocchi L. Factors affecting the fate of faecal diversion in patients with perianal Crohn's disease. Colorectal Dis 2015;17:66-72.

125. Régimbeau JM, Panis Y, Cazaban L, et al. Long-term results of faecal diversion for refractory perianal Crohn's disease. Colorectal Dis 2001;3:232-237.

126. Mennigen R, Heptner B, Senninger N, Rijcken E. Temporary fecal diversion in the management of colorectal and perianal Crohn's disease. Gastroenterol Res Pract 2015;2015:286315.

127. Kasparek MS, Glatzle J, Temeltcheva T, Mueller MH, Koenigsrainer A, Kreis ME. Long-term quality of life in patients with Crohn's disease and perianal fistulas: influence of fecal diversion. Dis Colon Rectum 2007;50:2067-2074.

128. Lewis RT, Maron DJ. Efficacy and complications of surgery for Crohn's disease. Gastroenterol Hepatol (N Y) 2010;6:587-596.

129. Ruffolo C, Scarpa M, Bassi N, Angriman I. A systematic review on advancement flaps for rectovaginal fistula in Crohn's disease: transrectal vs transvaginal approach. Colorectal Dis 2010;12:1183-1191.

130. Frizelle FA, Santoro GA, Pemberton JH. The management of perianal Crohn's disease. Int J Colorectal Dis 1996;11:227-237.

131. El-Gazzaz G, Hull T, Mignanelli E, Hammel J, Gurland B, Zutshi M. Analysis of function and predictors of failure in women undergoing repair of Crohn's related rectovaginal fistula. $J$ Gastrointest Surg 2010;14:824-829.

132. Gecse KB, Sebastian S, Hertogh G de, et al. Results of the Fifth Scientific Workshop of the ECCO [II]: clinical aspects of perianal fistulising Crohn's disease-the unmet needs. J Crohns Colitis 2016;10:758-765.

133. Sahnan K, Tozer P, Adegbola S, et al. Developing a core outcome set for fistulising perianal Crohn's disease. Gut 2018 (Epub ahead of print). 